\title{
Effect of Xerostomia on Quality of Life in Head and Neck Cancer Patients Undergoing Radiotherapy at RSUP H. Adam Malik Medan
}

\author{
Aida Fadhilla Darwis, Sayuti Hasibuan \\ Department of Oral Medicine \\ Faculty of Dentistry, Universitas Sumatera Utara \\ Medan, Indonesia \\ aida.1504@gmail
}

\author{
Hana Nuradinda Tarigan \\ Faculty of Dentistry, Universitas Sumatera Utara \\ Medan, Indonesia
}

\begin{abstract}
Xerostomia is one of the most common complications caused by head and neck cancer radiotherapy. Radiation caused the structure of the salivary glands change thus the saliva production was reduced. This can significantly affect the quality of life of the patients by changing physical, psychological and social function, pain which had an impact on the successful of the radiotherapy treatment. The purpose of this study was to analyze the effect of xerostomia on the quality of life among head and neck cancer patients undergoing radiotherapy at RSUP H. Adam Malik Medan. This was an observational analytic research with cross sectional study approach. 40 subjects of head and neck cancer patients undergoing radiotherapy selected by purposive sampling and data were collected by medical records, anamnesis, and interview. The results of study showed from the 40 subjects, 26 patients $(65 \%)$ with xerostomia have low quality of life $(57.7 \%)$, while 14 patients $(35 \%)$ that not experiencing xerostomia has higher quality of life $(85.7 \%)$. In conclusion, it is proven that there were significant relationship $(\mathrm{p}=0.008)$ between xerostomia and the quality of life among the head and neck cancer patients undergoing radiotherapy.
\end{abstract}

Keywords-Radiotherapy, head and neck cancer, xerostomia, quality of life

\section{INTRODUCTION}

Cancer is an abnormal cell or tissue multiplication which can be invasive or metastasis and consitute to be the one of the deadly disease. National Cancer Registration in Indonesia ranked head and neck cancer as the fourth of the top ten malignant disease [1]. Head and neck cancer prevalence was high in Indonesia $(4.7 / 100,000)$ [2].

Head and neck cancer can be treated with surgery, radiotherapy or both [3]. Radiotherapy is one of the most common treatment modality for head and neck cancer. However radiotherapy can cause several side effect for the body. Radiation can cause skin disorders, fatigue, nausea, and oral cavity such as xerostomia, mucositis, candidiasis and others [4]. In a study conducted by Pytko-Polonczyk and Macura, it was shown that mucositis, candidiasis, xerostomia can be found after two weeks of radiotherapy with precentage, respectively $54.9 \%, 41.5 \%, 54.9 \%$ from all patients [5].
Xerostomia is the most common problem in head and neck cancer patients undergoing radiotherapy. Patients undergoing conventional radiotherapy has been reported to experience xerostomia about $60 \%$ to $93 \%$ in patients [6]. Parenchymal loss and fibrosis of the salivary gland will occur due to radiation which can cause reduction of the salivary secretion [7]. Patients with xerostomia complain of burning sensation, masticating, swallowing, speech difficulties, and lost of taste [4]. That condition can affect quality of life of the patients [8]. WHO defines quality of life (QoL) as individuals perception of their position in life in the context of the culture and value systems in which they live and in relation to their goals, expectations, standards and concerns [9]. QoL assessment is a way to determine success of the treatment [10].

Kakoei et al. studies found that increasing one score in xerostomia can decreasing 1.65\% mean score of QoL [6]. Study conducted by Taher reported that QoL in patients after radiotherapy for head and neck cancer are worsened [11]. Based on the prevalence of head and neck cancer cases in Indonesia, the large number of head and neck cancer patientsat RSUP H. Adam Malik Medan, and the patients who experience xerostomia after undergoing radiotherapy, it is important to knew the effect of xerostomia on quality of life and the quality of life level of head and neck cancer patients undergoing radiotherapy at RSUP H. Adam Malik Medan.

\section{MATERIALS AND METHODS}

\section{A. Patients and Setting}

In an observational analytic research with cross sectional approach design, the population of this study were head and neck cancer patients undergoing radiotherapy at RSUP H. Adam Malik Medan.

This study was approved under the ethical code of 282/TGL/KEPK FK USU-RSUP HAM/2017 by theHealth Research Ethical Committee, Medical Faculty Of Universitas Sumatera Utara/ H. Adam Malik General Hospital.

40 subjects were obtained by purposive sampling with the criteria of head and neck cancer patients who 
received only radiotherapy treatment, absence of systemic disease (Sjogren's Syndrome, lupus, Parkinson's, chronic renal failure, thyroid dysfunction, AIDS), and did not take any medications (anti anxiety, anti psychotic, anti hypertension). While patients who are unable to open their mouths and uncooperative was excluded from this study.

\section{B. Assessments}

The data was collected by medical records, anamnesis, and interviewed the patients. Having explained the objectives of study and its methodology, eligible subjects were asked to sign a consent form at first. Subjecst were asked to complete a questionnaire related to their xerostomia and a QoL questionnaire.

Data was collected using Summated Xerostomia Inventory (XI) and QoL questionnaire. The Summated Xerostomia Inventory included five questions evaluated by scale 1: Never; 2: Occasionally; and 3: Often. Patients who had XI score larger than five will be diagnosed with xerostomia. Hence, according to the XI, the more the patient had a feeling of xerostomia, the higher the xerostomia score wold be, which range beetween 5-15 [12]. For QoL, we used the QoL qestionnaire published by Dirix et al. In that study, 15 questions evaluated QoL with Likert scale, as follows: 1: not at al; 2: a little; 3: moderately; 4: quite a lot; and 5: very much. The worse the patients QoL was, the higher its score would be. This score ranged between 15-75. In addition to these questions, demographic information of age, sex, cancer location, and total dose the patients already received [8].

\section{Statistical Analysis}

Data were analyzed using SPSS. We compared the xerostomia and QoL scores byChi-Square test $\left(\mathrm{X}^{2}\right)$.

\section{RESULTS}

In this study, there were 27 male $(67.5 \%)$, and 13 female $(32.5 \%)$. Based on age, 11 patients $(27.5 \%)$ in the age group $46-55$ years, 10 patients $(25 \%)$ in the age group 36-45 years, 9 patients $(22.5 \%)$ in the age group $56-65$ years, 5 patients $(12.5 \%)$ in the age group $25-35$ years, 3 patients $(7.5 \%)$ in the age group $>65$ years and 2 patients $(5 \%)$ in the age group 17-25years. Based on the location of the cancer, most of the subjects experienced cancer in nasopharyngeal, oral cavity, salivary gland, larynx, nasal cavity with percentage, respectively $75 \% 15 \%, 5 \%, 5 \%$, and $0 \%$ (Table I).

Subjects with xerostomia were 26 patients $(65 \%)$ while 14 patients $(35 \%)$ were not experiencing xerostomia (Table II).

The majority of subjects who had xerostomia were in the 20-28 Gy group with 9 patients $(34.6 \%)$ and the majority of subjects who are not experiencing xerostomia were in the 10-18 Gy group with 9 patients (64.2\%) (Table III).
TABLE I. PATIENT AND CANCER CHARACTERISTICS

\begin{tabular}{|c|c|c|}
\hline Characteristic & $\begin{array}{c}\text { Number of Patients } \\
(n=40)\end{array}$ & Percent $(\%)$ \\
\hline \multicolumn{3}{|l|}{ 1. Sex } \\
\hline a. Male & 27 & $67.5 \%$ \\
\hline b. Female & 13 & $32.5 \%$ \\
\hline \multicolumn{3}{|l|}{ 2. Age } \\
\hline a. $17-25$ & 2 & $5 \%$ \\
\hline b. $26-35$ & 5 & $12.5 \%$ \\
\hline c. $36-45$ & 10 & $25 \%$ \\
\hline d. $46-55$ & 11 & $27.5 \%$ \\
\hline e. $56-65$ & 9 & $22.5 \%$ \\
\hline f. $>65$ & 3 & $7.5 \%$ \\
\hline \multicolumn{3}{|l|}{ 3. Cancer Location } \\
\hline a. Nasopharyngeal & 30 & $75 \%$ \\
\hline b. Oral cavity & 6 & $15 \%$ \\
\hline c. Salivary gland & 2 & $5 \%$ \\
\hline d. Larynx & 2 & $5 \%$ \\
\hline e. Nasal cavity & 0 & $0 \%$ \\
\hline
\end{tabular}

\section{TABLE II. INCIDENCE OF XEROSTOMIA}

\begin{tabular}{|c|c|c|}
\hline Xerostomia & Frequency & \% \\
\hline Xerostomia (+) & 26 & 65 \\
\hline Xerostomia (-) & 14 & 35 \\
\hline Total & 40 & 100 \\
\hline
\end{tabular}

TABLE III. XEROSTOMIA AND RADIATION DOSAGE

\begin{tabular}{|c|c|c|c|c|c|}
\hline \multirow{3}{*}{ Radiation dosage } & \multicolumn{5}{|c|}{ Xerostomia Incidence } \\
\cline { 2 - 5 } & \multicolumn{2}{|c|}{ Xerostomia (+) } & \multicolumn{2}{|c|}{ Xerostomia (-) } & \multirow{2}{*}{ N } \\
\cline { 2 - 5 } & $\mathbf{F}$ & $\mathbf{\%}$ & $\mathbf{F}$ & $\mathbf{\%}$ & \\
\hline $10-18$ Gray & 7 & $26.9 \%$ & 9 & $64.2 \%$ & 16 \\
\hline $20-28$ Gray & 9 & $24.6 \%$ & 2 & $14.2 \%$ & 11 \\
\hline $30-38$ Gray & 4 & $15.3 \%$ & - & - & 4 \\
\hline 40-48 Gray & - & - & 1 & $7.1 \%$ & 1 \\
\hline 50-58 Gray & 5 & $19.2 \%$ & 1 & $7.1 \%$ & 6 \\
\hline 60-70 Gray & 1 & $7.1 \%$ & 1 & $7.1 \%$ & 2 \\
\hline Total & 26 & $100 \%$ & 14 & $100 \%$ & 40 \\
\hline
\end{tabular}

QoL was assessed based on Xerostomia Related Quality of Life Scale questionnaire. Majority of subjects with xerostomia (77\%) felt restricted in amount and/or type of food, had an uncomfortable feeling in their mouth $(73 \%)$, made them felt worry and concern $(47 \%)$, made them felt awkward to ate in front of other people (54\%), made them not enjoyed life $(69 \%)$, restricts their daily activities (88\%), gave their food less or a different taste $(88 \%)$, reduced their general happiness with life $(65 \%)$, made them felt that they cannot stay in xerostomia condition for the rest of their life $(74 \%)$, and felt that xerostomia invaded every aspect of their live $(81 \%)$. However, many subjects did not complain about xerostomia restricted their social life $(64 \%)$, did not made them difficult to speak to other people $(67 \%)$, did not made them nervous (62\%), did not made them worry about the look of their teeth and mouth (65\%), and did not gave troubles with their intimate relation $(62 \%)$ (Table IV). 
TABLE IV. RESULT OF XEROSTOMIA RELATED QUALITY OF LIFE QUESTIONNAIRE

\begin{tabular}{|c|c|c|c|c|c|}
\hline \multirow{2}{*}{$\begin{array}{c}\text { My Dry } \\
\text { Mouth.... }\end{array}$} & \multicolumn{5}{|c|}{ Scale } \\
\hline & $\begin{array}{c}\text { Not } \\
\text { at all }\end{array}$ & $\begin{array}{c}\mathbf{A} \\
\text { little }\end{array}$ & Moderate & $\begin{array}{l}\text { Quite } \\
\text { a lot }\end{array}$ & $\begin{array}{l}\text { Very } \\
\text { much }\end{array}$ \\
\hline $\begin{array}{c}\text { Restricts the } \\
\text { amount and type } \\
\text { of food I eat }\end{array}$ & $23 \%$ & $8 \%$ & $31 \%$ & $23 \%$ & $15 \%$ \\
\hline $\begin{array}{l}\text { Gives me an } \\
\text { uncomfortable } \\
\text { feeling in my } \\
\text { mouth }\end{array}$ & $27 \%$ & $15 \%$ & $31 \%$ & $19 \%$ & $8 \%$ \\
\hline $\begin{array}{c}\text { Makes me } \\
\text { worry and } \\
\text { concern }\end{array}$ & $54 \%$ & $8 \%$ & $12 \%$ & $27 \%$ & $0 \%$ \\
\hline $\begin{array}{l}\text { Restricts my } \\
\text { social life }\end{array}$ & $64 \%$ & $12 \%$ & $20 \%$ & $4 \%$ & $0 \%$ \\
\hline $\begin{array}{c}\text { Makes it } \\
\text { awkward to eat } \\
\text { in front of other } \\
\text { people }\end{array}$ & $46 \%$ & $27 \%$ & $12 \%$ & $15 \%$ & $0 \%$ \\
\hline $\begin{array}{c}\text { Makes it } \\
\text { difficult to } \\
\text { speak to other } \\
\text { people }\end{array}$ & $67 \%$ & $15 \%$ & $15 \%$ & $4 \%$ & $0 \%$ \\
\hline $\begin{array}{c}\text { Makes me } \\
\text { nervous }\end{array}$ & $62 \%$ & $4 \%$ & $12 \%$ & $19 \%$ & $4 \%$ \\
\hline $\begin{array}{c}\text { Makes me } \\
\text { worry about the } \\
\text { look of my teeth } \\
\text { and mouth }\end{array}$ & $65 \%$ & $8 \%$ & $19 \%$ & $8 \%$ & $0 \%$ \\
\hline $\begin{array}{c}\text { Keeps me from } \\
\text { enjoying life }\end{array}$ & $31 \%$ & $38 \%$ & $27 \%$ & $4 \%$ & $0 \%$ \\
\hline $\begin{array}{c}\text { Restricts me in } \\
\text { my daily } \\
\text { activities }\end{array}$ & $12 \%$ & $42 \%$ & $38 \%$ & $8 \%$ & $0 \%$ \\
\hline $\begin{array}{c}\text { Troubles my } \\
\text { intimate relation }\end{array}$ & $62 \%$ & $23 \%$ & $15 \%$ & $0 \%$ & $0 \%$ \\
\hline $\begin{array}{c}\text { Gives my food } \\
\text { less or a } \\
\text { different taste }\end{array}$ & $12 \%$ & $0 \%$ & $19 \%$ & $4 \%$ & $65 \%$ \\
\hline $\begin{array}{l}\text { Reduces my } \\
\text { general } \\
\text { happiness with } \\
\text { life }\end{array}$ & $35 \%$ & $38 \%$ & $19 \%$ & $8 \%$ & $0 \%$ \\
\hline $\begin{array}{c}\text { Invades every } \\
\text { aspect of my } \\
\text { live }\end{array}$ & $19 \%$ & $42 \%$ & $31 \%$ & $8 \%$ & $0 \%$ \\
\hline $\begin{array}{l}\text { Cannot stay like } \\
\text { this for the rest } \\
\text { of my life }\end{array}$ & $27 \%$ & $27 \%$ & $31 \%$ & $12 \%$ & $4 \%$ \\
\hline
\end{tabular}

The mean QoL score in this study was 28.4. The subjects who had xerostomia with low quality of life were 15 patients $(57.7 \%)$ while 11 patients $(42.3 \%)$ had high quality of life. Meanwhile, the subjects who are not experiencing xerostomia with low quality of life were 2 patients $(14.35 \%)$ and 12 patients $(85.7 \%)$ had high quality of life (Table V).

TABLE V. XeROSTOMIA AND QuALITY OF LIFE

\begin{tabular}{|c|c|c|c|c|}
\hline \multirow{2}{*}{$\begin{array}{c}\text { Quality } \\
\text { of Life }\end{array}$} & \multicolumn{2}{|c|}{ Xerostomia (+) } & \multicolumn{2}{c|}{ Xerostomia (-) } \\
\cline { 2 - 5 } High & Frequency & \% & Frequency & \% \\
\hline Low & 11 & $42.3 \%$ & 12 & $85.7 \%$ \\
\hline Total & 15 & $57.7 \%$ & 2 & $14.3 \%$ \\
\hline
\end{tabular}

The result of statistic test using Chi-square shows that $\mathrm{p}=0.008$ which mean there was a significant relationship between xerostomia and the quality of life among the head and neck cancer patients undergoing radiotherapy (Table VI).

TABLE VI. RESULTS OF CHI-SQUARE ANALYSIS

\begin{tabular}{|c|c|c|c|c|}
\hline \multirow{2}{*}{ Xerostomia } & \multicolumn{2}{|c|}{ Quality of Life } & \multirow{2}{*}{$\mathbf{n}$} & \multirow{2}{*}{ p } \\
\cline { 2 - 3 } & High & Low & & \\
\hline Xerostomia (+) & $11(42.3 \%)$ & $15(57.7 \%)$ & 26 & 0.008 \\
\hline Xerostomia (-) & $12(85.7 \%)$ & $2(14.3 \%)$ & 14 & \\
\hline Total & 23 & 17 & 40 & \\
\hline
\end{tabular}

\section{DISCUSSION}

Xerostomia refers to a subjective sensation of dry mouth, it is frequently, but not always, associated with salivary gland hypo function [13]. Xerostomia can cause discomfort such as sore throat, altered taste, dental decay, changes in voice quality and impaired chewing and swallowing function then affect the patients QoL [14,20].

In this study, there were $67.5 \%$ male and $32.5 \%$ female that suffering head and neck cancers. In previous study of head and neck cancer patients, To'bungan et al. shows that male has a high percentage which was $52.7 \%$ [1]. Kurniasari et al. reported that comparison of male and female in head and neck cancer case was 3:1.2. Generally, head and neck cancer was related to several factors such as habit, occupation and environmental exposure. Commonly, male has a habit to smoke and drink alcohol. Substances contained in cigarettes such as tar, nitrosamines and others can lead to cancer $[1,15]$.

Based on the age group of subjects, subjects who had head and neck cancer mostly was $46-55$ years. In previous study conducted by Larizadeh et al. the majority patients with head and neck cancer was in the 51-60 years age group [16]. As we grow old physiological function especially the immune system will be decreased. Decreased of immune system can cause inability to destroy cancer cells. Elderlywill be more susceptible to stress and fatigue, has a poor eating patterns which can disrupt the balance of the immune system and cancer cells will be more invasive [17].

Based on the location of the cancer, most of the subjects experienced nasopharyngeal cancer $(75 \%)$. In previous study conducted by Adham et al. at Dr. Cipto Mangunkusumo Hospital Jakarta, the highest incidence of head and neck cancer patients was nasopharyngeal cancer. Lack of awareness of factors that can lead to nasopharyngeal cancer such as Epstein-Barr Virus (EBV). NPC is $100 \%$ related to EBV infection, especially the most common undifferentiated type of NPC (WHO type III). Primary infection usually occurs at childhood and is asymptomatic. In Indonesia, 100\% of children at 5 years of age are infected with EBV and carry latent virus for life. NPC oncogenesis is not simply a consequence of EBV infection alone. The transformation of EBV infection into a malignant disease is probably a result of viral reactivation in combination with environmental carcinogens and bad lifestyle leads to nasopharyngeal cancer [18].

In this study, subjects with xerostomia were 26 patients $(65 \%)$. This study had a similar result as the 
previous study by Jham et al. that shows $62.6 \%$ head and neck cancer patient undergoing radiotherapy had xerostomia [19]. Radiation exposure from radiotherapy can cause damaged to the healthy tissue such as salivary glands then induced xerostomia [4]. Several studies explain that xerostomia is the most common oral complication in head and neck cancer patients undergoing radiotherapy $[4,5,6,8,19]$. Radiation will cause apoptosis acinar cells and degenerate acinar epithelium. This condition will caused decreasing saliva secretion [20].

Xerostomia experienced by most subjects were in the group who received radiation of 20-28 Gy (34.6\%), while subjects whom not experiencing xerostomia most in the group that received radiation 10-18 Gy (64.2\%). The number and severity of salivary gland tissue in radiotherapy patients with xerostomia depends on the dose and duration of irradiation [4]. In the study conducted by Blanco et al. decreased salivary gland function mounted at dose 20-40 Gy. The dose of radiotherapy can affect the salivary glands. Radiation dose < 10 Gray may cause salivary gland inflammation resulting in reduced salivary secretions, 10-15 Gy may cause parenchymal tissue shrinkage resulting blockage of salivary glands and xerostomia beginning to show up resulting in dry mouth complaints, and 15- 40 Gy causes the blockage of the salivary glands to become widespread resulting in fibrosis and cause a reversible reduction of saliva [20].

Quality of Life Scale questionnaire have a score range 15-75. The mean QoL score in this study was 28.4. It mean that the QoL of a subject will be high if the score was below 28.4 and the quality of life was low if the score larger than 28.4. Results of this study was different from Dirix, et al. who had a 65.6 mean score of XeQoLS. Differences in the research methods, involving large quantities of the subjects and high prevalence of xerostomia (93\%) [8]. In this study, $57.7 \%$ subjects who had xerostomia had low quality of life while $85.7 \%$ subjects who are not experiencing xerostomia had high quality of life. In previous study conducted by Lin et al. patients with xerostomia had a low quality of life due to radiotherapy [21]. Complained of dysphagia, loss of taste sensation, and caries, from the patients can affect the QoL [4].

In this study, subjects felt xerostomia affect the QoL by changing their function of physical, psychological, social, and pain issues. Most of the subjects felt their physical function changed such as felt restricted in amount and/or type of food (77\%), restricts their daily activities $(88 \%)$, gave their food less or a different taste (88\%), even though it did not made them difficult to speak to other people (67\%). Subjects also felt that their psychological function changed such as xerostomia reduced their general happiness with life (65\%), invaded every aspect of their live (81\%), and made them felt that they cannot stay in xerostomia condition for the rest of their life (74\%), even though it did not made them worry about the look of their teeth and mouth (65\%). Meanwhile for the social function, subjects did not complain xerostomia restricted their social life $(64 \%)$, and did not gave troubles with their intimate relation $(62 \%)$. However it made them felt awkward to ate in front of other people (54\%). Subjects also did not complain about pain issues such as xerostomia did not made them nervous $(62 \%)$, did not made them felt worry and concern (47\%), but subjects complain about an uncomfortable feeling in their mouth (73\%), and made them not enjoyed their life (69\%). The results in this study was similar to the study conducted by Dirix et al. that shows the number of patients who felt the disruption of aspects of QoL due to impaired function of physical, social, psychological, and pain issues [8]. The difference in this study with Dirix, et al was the subject in this study more complained about the disruption of physical and psychological functions compared with social function and pain issues. In a study conducted by Kakoei et al.it seemed that the psychological shock that patients may have at the time of diagnosis and in the beginning of treatment manifest as xerostomia even in the absence of a considerable decrease in saliva amount [6].

Cross-tabulation between xerostomia on the quality of life among head and neck cancer patients undergoing radiotherapy showed $\mathrm{p}=0.008$ means that there was a significant relationship between xerostomia and quality of life. In the previous study conducted by Dirix et al. there was a significant relationship between xerostomia and quality of life [8]. In study conducted by Kakoei et al. the increased score of xerostomia would worsen the quality of life of patients. Patients undergoing radiotherapy of the head and neck areas can experiencing xerostomia which caused a disruption of the quality of life [7]. Quality of life is important for health in order to measure the success of treatment and improve patients life [9]. The limitation of our study was we only interviewed the subjects with XI to diagnosed xerostomia. However, other way to diagnosed xerostomia such as collecting the subjects saliva seems more accurate because radiation cause damage to salivary gland.

As a conclusion in this research, it was proven that there were significant relationship between xerostomia and the quality of life among the head and neck cancer patients undergoing radiotherapy. Assessment of QoL can determine success of the treatment and the patient's life. Therefore, early diagnosed of xerostomia is important for head and neck cancer patients undergoing radiotherapy so they can get the right treatment and improve their QoL by oral health improvement.

\section{REFERENCES}

[1] N. To'Bungan, S.H. A'liyah, N. Wijayanti, J, "Fachirih Epidemiologi, stadium, dan derajat diferensiasi kanker kepala dan leher," Biogenesis, vol. 3(1), pp. 47, 2015.

[2] F. Kurniasari, A. Surono, R. Pangustuti, "Status gizi sebagai prediktor kualitas hidup pasien kanker kepala dan leher,' Indonesian Journal of Human Nutrition, vol. 2(1), pp. 61, 2015.

[3] A. Jawad, N.A. Hodson, P.J Nixon PJ, "A review of dental treatment of head and neck cancer patients, before during and after radiotherapy: part 1," British Dental Journal, vol. 218(2), pp. $65,2015$. 
[4] K. Rao, R.L. Castelino, U. Shetty, G. Babu, "A review of postradiotherapy complications necessitating an urgency for further advances and innovations in radiotherapy," Austin Journal of Radiology, vol. 2(4), pp. 2, 2015.

[5] Pytko-Polonczyk J, Macura A. Dental care for cancer patients undergoing radiotherapy of the head and neck region. Journa of Pre-Clinical and Clinical Research; 6(2): 113, 2012.

[6] S. Kakoei, A. Haghdoost, M. Rad, "Xerostomia after radiotherapy and its effect on quality of lofe in head and neck cancer patients," Archives of Iranian Medicine, vol. 15(4), pp. 214, 2012.

[7] O. Grundmann, G.C. Mitchell, K.H. Limesand, "Sensitivity of salivary glands to radiation," J. Dent. Res., vol. 88(10), pp. 895, 2009.

[8] P. Dirix, S. Nuyts, V.V. Poorten, "The influence of xerostomia after radiotherapy on quality of life," Support Care Cancer, vol. 16 , pp. $175,2008$.

[9] WHO. (2017, January 28) WHOQOL Measuring quality of life. Avaiable: http://www.who.int/mental_health/media/68.pdf.

[10] P. D’Souza, J. Chakrabarty, B. Sulochana, G. James, “Quality of Life of Head and Neck Cancer Patients Receiving Cancer Specific Treatments," Journal of Krishna Institute of Medical Sciences University, vol. 2(1), pp. 56, 2013.

[11] A. Taher, "Head and Neck Cancer: Closer Look at Patients Quality of Life," Journal of Cancer Therapy, vol. 7, pp. 126, 2016.

[12] W. Thompson, G. Putten, C. Baat, K. Matsuda, Hopcraft, "Shortening the xerostomia inventory," Oral Surg. Oral Med. Oral Pathol. Oral Radiol. Endod., vol. 20(10), pp. 3-4, 2011.
[13] N. Sultana, M. Sham, "Xerostomia: an overview," International Journal of Dental Clinics, vol. 3(2), pp. 58-61, 2001

[14] J.O. Deasy, V. Moiseenko, L. Marks, K.S. Chao, "Radiotherapy dose-volume effects on salivary gland function," Int. J. Radiation Oncolgy Biologi Physics, vol. 76(3), pp. 58-63, 2010.

[15] A. Tariq, Y. Mehmood, M. Jamshaid, H. Yousaf, "Head and neck cancers: incidence, epidemiological risk, and treatmen options," International Journal of Pharmaceutical Research \& Allied Sciences, vol. 4(3), pp. 21, 2015.

[16] M. Larizadeh, M. Damghani, M. Shabani, "Epidemiologica characteristics of head and neck cancers in Southeast of Iran," Iranian Journal of Cancer Prevention, vol. 2, pp. 81, 2014.

[17] V. Suhag, B. Sunitas, Sarin, "A challenges in cancer care of elderly," International Journal of Medical Physics, Clinical Engineering and Radiation Oncology, vol. 4, pp. 26, 2015.

[18] M. Adham, A. Kurniawan, A. Muhtadi, et al., "Nasopharyngeal carcinoma in Indonesia: epidemiology, incidence, signs, and symptos at presentation," Chinese Journal of Cancer, vol. 31(4), pp. 186, 188, 2012.

[19] B.C. Jham, P.M. Reis, E.L. Miranda, "Oral health status of 207 head and neck cancer patients before, during and after radiotherapy," Clin. Oral Invest., vol. 12, pp. 19, 2008.

[20] G. Baijal, R. Kar, J.P. Agarwal, "Radiation-Induced Xerostomia," International Journal of Head and Neck Surgery, vol. 3(2), pp. 82, 2012.

[21] S. Lin, Y. Jen, Y. Chang, C. Lin, "Assessment of xerostomia and its impact on quality of life in head and neck cancer patients undergoing radiotherapy, and validation of the Taiwanese version of the xerostomia questionnaire," Journal of Pain and Symptom Management, vol. 36(2), pp. 147, 2008 